\title{
Ageusia and anosmia, a common sign of COVID-19? A case series from four countries
}

\author{
Jair Vargas-Gandica ${ }^{1,2}$ - Daniel Winter ${ }^{1}$ Rainer Schnippe ${ }^{1} \cdot$ Andrea G. Rodriguez-Morales $^{2,3} \cdot$ Johana Mondragon $^{2}$. \\ Juan Pablo Escalera-Antezana ${ }^{2,4,5}$. María del Pilar Trelles-Thorne ${ }^{6}$ • D. Katterine Bonilla-Aldana ${ }^{2,7,8}$. \\ Alfonso J. Rodriguez-Morales ${ }^{2,5,8,9,10}$ (1) . Alberto Paniz-Mondolfi ${ }^{2,6,10,11,12,13}$
}

Received: 2 May 2020 /Revised: 5 June 2020 / Accepted: 15 June 2020 / Published online: 14 July 2020

(C) Journal of NeuroVirology, Inc. 2020

\begin{abstract}
Over the course of the pandemic due to the severe acute respiratory syndrome coronavirus 2 (SARS-CoV-2), multiple new clinical manifestations, as the consequence of the tropism of the virus, have been recognized. That includes now the neurological manifestations and conditions, such as headache, encephalitis, as well as olfactory and taste disorders. We present a series of ten cases of RT-PCR-confirmed SARS-CoV-2-infected patients diagnosed with viral-associated olfactory and taste loss from four different countries.
\end{abstract}

Keywords Anosmia $\cdot$ Ageusia $\cdot$ Clinical manifestations $\cdot$ Neurological $\cdot$ SARS-CoV-2 $\cdot$ COVID-19

\section{Introduction}

As the severe acute respiratory syndrome coronavirus 2 (SARS-CoV-2) pandemic continues to evolve, novel signs and symptoms continue to emerge and expand the clinical manifestations of coronavirus disease 2019 (COVID-19) (Rodriguez-Morales et al. 2020a). This includes an ever- increasing number of reports linking the virus to a number of presumed neurological disorders (Paniz-Mondolfi et al. 2020).

The spectrum of neurological manifestations includes headache (Rodriguez-Morales et al. 2020b), encephalitis, GuillainBarre syndrome (Zhao et al. 2020), as well as olfactory and taste dysfunction (Ollarves-Carrero et al. 2020). Despite recognition of these symptoms, there is still a lack of reports,
Alfonso J. Rodriguez-Morales

arodriguezm@utp.edu.co

1 Klinik für Allgemeine Innere Medizin, Sankt Vinzenz Hospital, Rheda-Wiedenbrück, Germany

2 Latin American Network of Coronavirus Disease 2019-COVID-19 Research (LANCOVID-19), Pereira, Risaralda, Colombia

3 Unidad Procedimientos, Policlínico Neurología, Centro de Referencia de Salud Dr. Salvador Allende Gossens, Santiago de Chile, Chile

4 National Telehealth Program, Ministry of Health, La Paz, Bolivia

5 Universidad Privada Franz Tamayo/UNIFRANZ, Cochabamba, Bolivia

6 Icahn School of Medicine at Mount Sinai, New York, NY, USA

7 Semillero de Zoonosis, Grupo de Investigación BIOECOS, Fundación Universitaria Autónoma de las Américas, Sede Pereira, Pereira, Risaralda, Colombia
8 Public Health and Infection Research Group, Faculty of Health Sciences, Universidad Tecnologica de Pereira, Pereira, Risaralda, Colombia

9 Grupo de Investigación Biomedicina, Faculty of Medicine, Fundación Universitaria Autónoma de las Américas, Pereira, Risaralda, Colombia

10 Committee on Travel Medicine, Pan-American Infectious Diseases Association, Asuncion, Paraguay

11 Laboratorio de Señalización Celular y Bioquímica de Parásitos, Instituto de Estudios Avanzados (IDEA), Caracas, Caracas, Venezuela

12 Academia Nacional de Medicina, Caracas, Venezuela

13 Instituto de Investigaciones Biomedicas IDB / Incubadora Venezolana de la Ciencia, Cabudare, Edo. Lara, Venezuela 
delving deeply into the clinical and pathophysiological aspects of SARS-CoV-2-related anosmia and ageusia. Herein, we present a series of ten cases of RT-PCR-confirmed SARSCoV-2-infected patients diagnosed with viral-associated olfactory and taste loss from four different countries. Of these, nine patients presented with ageusia and eight with anosmia, with seven of them presenting overlapping anosmia/ageusia persisting for a range of 4 to 25 days.

\section{Cases}

The median age of these COVID-19 patients was 48 years old, seven females and three males (Table 1). Patients 1 and 3 were related, as well as patients 5 and 6 . Four patients were from Germany, three from the USA, two from Venezuela, and one from Bolivia. Eight referred cough as the most common presenting symptom, with only five presenting fever. Other symptoms included dyspnea, generalized weakness, headache, diarrhea, dehydration, polyarthralgia, nausea, and vomiting (Table 1). Patients 1, 4, and 7 required hospitalization for 17,15 , and 10 days, respectively. Notably, ageusia and anosmia were among the most common signs found in all patients with a median time of presentation at 2 days after onset of symptoms for ageusia and 3 days for anosmia.

Anosmia was the debuting clinical sign in three patients, of whom two presented with olfactory loss at day 1 , and one (patient 7), 2 days previous to the onset of symptoms. Ageusia was also an early sign, presenting between days 1 and 2 in five patients and between days 4 and 5 in three. Late-onset anosmia (day 7) and ageusia (day 10) was observed in patient 10. Ageusia persisted for a median of 8 days (ranging 4 to 25) and anosmia for a mean of 11 days ( 5 to 25 ). In two patients, co-infection with the influenza virus was assessed, resulting negative by RT-PCR in patients 1 and 4 (Table 1). Patient 1 had repeated positive RTPCR testing for SARS-CoV-2 at days 6, 10, 11, and 17 of disease.

\section{Discussion}

Our results, from four very different countries in Europe, North and South America, are consistent with those found by other groups were postviral olfactory loss presents more commonly in women, with a female-to-male ratio of 2:1 and typically over 50 years of age (Seiden 2004). Concurrent affectation of the sense of taste suggests that most probably ageusia in these patients is secondary to a diminished taste perception as a consequence of anosmia. However, sensorineural impairment due to direct viral injury cannot be entirely excluded (Elterman et al. 2014; Rahban et al. 2015).

Recent data suggest that smell and taste disorders may be significantly more frequent among COVID-19 patients than influenza patients (Hopkins et al. 2020; Lechner et al. 2020; Lee et al. 2020; Moein et al. 2020; Reinhard et al. 2020; Tong et al. 2020). As we observed in our patients, deficits in olfactory and taste function were usually of acute onset and at early stages of the disease, presenting for most cases as the initial clinical manifestation throughout the first days (Beltran-Corbellini et al. 2020). In a recent case-control study with 17 patients with smell and taste disorders, the mean duration of symptoms was 7.5 days (Beltran-Corbellini et al. 2020). To date, despite the massive ongoing pandemic affecting over 9.18 million people worldwide, as of June 23, 2020, there is limited information regarding the real prevalence of ageusia, anosmia, and other sensorineural related disorders associated to SARS-CoV-2 infection from Latin America. Olfactory and taste dysfunction has been reported as a clinical manifestation of a wide range of viral infections, particularly those causing upper respiratory tract infections (Seiden 2004).

However, these symptoms are usually attributed as conductive or obstructive signs due to mucosal edema and not as direct sensorineural noxa by the virus, leading to substantial underreporting in a high proportion of patients (Seiden 2004). Multiple viruses are known to use the olfactory nerve as a shortcut into the central nervous systems, including the influenza virus, which can also lead to long-term olfactory disorders in some cases (Ollarves-Carrero et al. 2020; van Riel et al. 2015). Rhinovirus, respiratory syncytial virus, paramyxovirus, adenovirus, echovirus, and enterovirus have also been linked to cytopathic damage of the olfactory epithelium (Seiden 2004). Hypogeusia, dysgeusia, hyposmia, and dysosmia associated with COVID-19 require more detailed studies to understand their pathophysiology, but especially their clinical course and potential long-term implications (Ollarves-Carrero et al. 2020).

As the pandemic continues to expand, early detection and screening for suspicious cases, based on broader clinical findings, would be a useful aid to diagnosis, besides rRT-PCR confirmation; particularly in resource depleted settings such as Latin America were numerous regions are already reaching concerning epidemic proportions (Cimerman et al. 2020). Despite some reports, anosmia is not frequent in the context of common cold and flu. The typical flu or viral upper respiratory tract infection can cause changes in smell usually secondary to nasal congestion, but that does not appear to be the case with COVID-19. Our patients did not have any significant nasal congestion or obstruction. An increase in smell and taste disorders, in the context of the ongoing COVID-19 pandemic in Latin America, makes this case series of relevance.

We endorse the assessment of smell and taste disorders, such as ageusia and anosmia, as a critical component of the anamnesis and as a helpful diagnostic clue for COVID-19. Early recognition of these signs, along with flu-like symptoms, may aid in supporting individuals' self-isolation in the current epidemic context (Beltran-Corbellini et al. 2020). Finally, as a consequence of this, multiple national guidelines are considering both of these cardinal clinical signs as part of the constellation of findings 


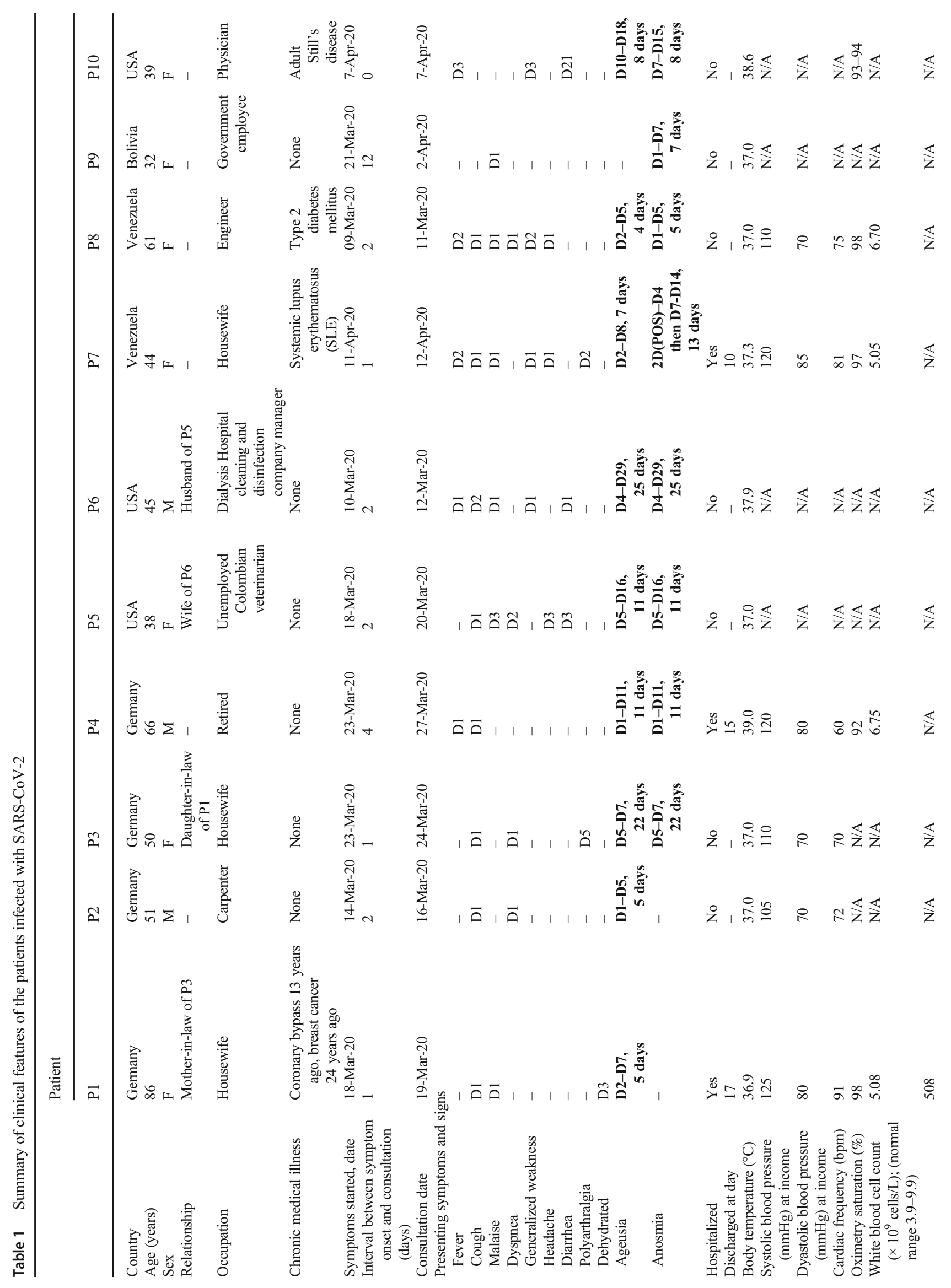




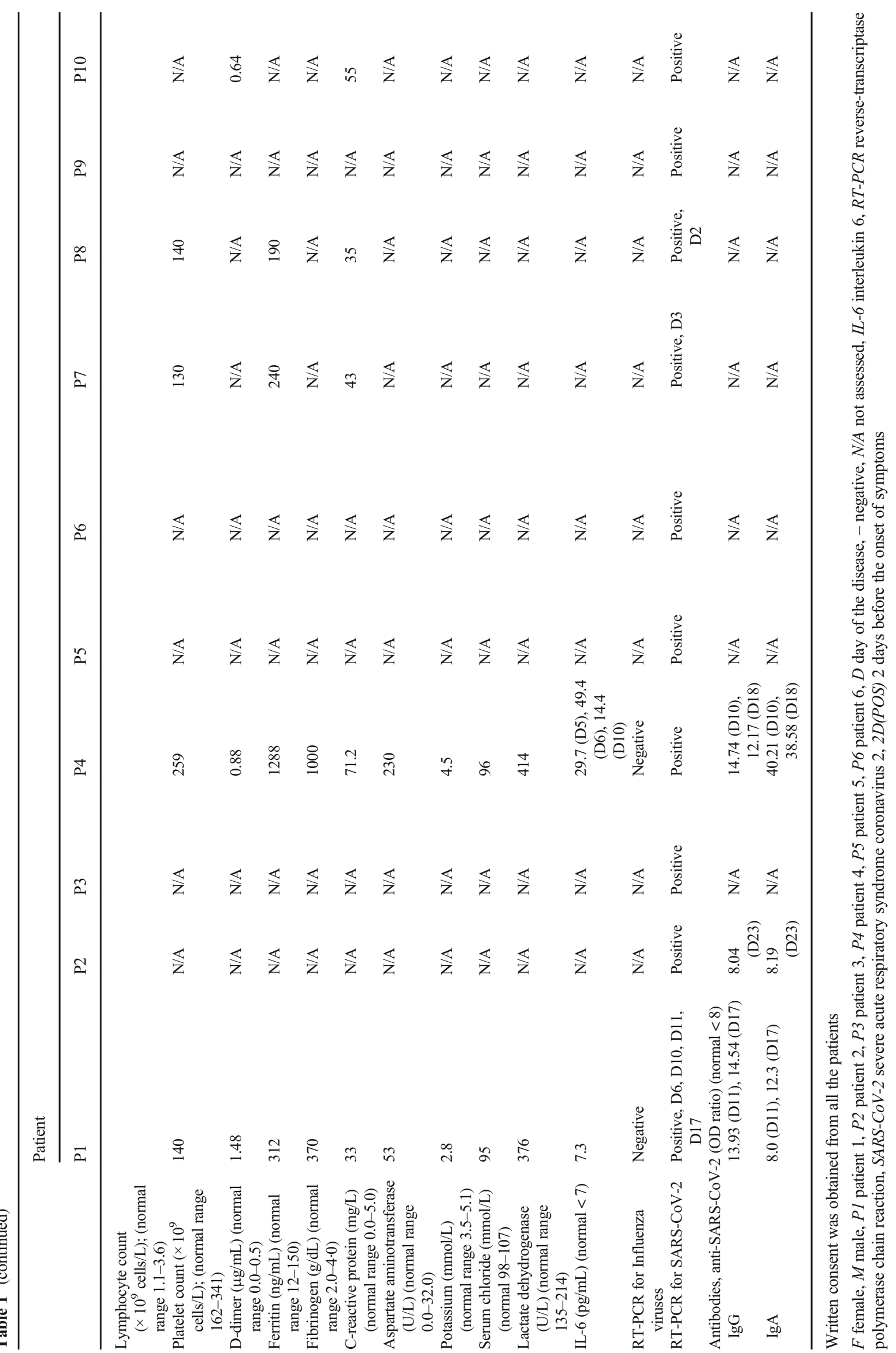


defining COVID-19. The Centers for Disease Control (CDC) in the USA now recognizes these as early symptoms for screening purposes (CDC 2020). In Latin America, these findings have already been even included in Chile and Colombia, also as COVID-19 suspicion criteria (Gutiérrez et al. 2020). In these countries, no cases of ageusia and anosmia have been reported to date associated with COVID-19.

Author contributions JAVG, AJRM, APM conceived the report. JAVG, AJRM, APM, DW, RS, JPEA, collected data, analyzed, and interpreted clinical data. AJRM wrote the first draft. AGRM, DKBA, performed a review of the literature. All authors approved the subsequent draft versions. All authors approved the final submitted version.

Data Availability Copy of the clinical data of the patients is available.

\section{Compliance with ethical standards}

Written consent from all the patients was obtained. Written consent from the patient was obtained for publication.

Conflict of interest We declare that we have no competing interests, except JM and MPTT; they are the patients 5 and 10 of this case series.

\section{References}

Beltran-Corbellini A, Chico-Garcia JL, Martinez-Poles J, RodriguezJorge F, Natera-Villalba E, Gomez-Corral J, Gomez-Lopez A, Monreal E, Parra-Diaz P, Cortes-Cuevas JL, Galan JC, FragolaArnau C, Porta-Etessam J, Masjuan J, Alonso-Canovas A (2020) Acute-onset smell and taste disorders in the context of Covid-19: a pilot multicenter PCR-based case-control study. Eur J Neurol. https://doi.org/10.1111/ene. 14273

CDC (2020). Coronavirus disease 2019 (COVID-19) - Symptoms of coronavirus. https:/www.cdc.gov/coronavirus/2019-ncov/ symptoms-testing/symptoms.html

Cimerman S, Chebabo A, Cunha CAd, Rodríguez-Morales AJ (2020). Deep impact of COVID-19 in the healthcare of Latin America: the case of Brazil. The Brazilian Journal of Infectious Diseases 24:93-95

Elterman KG, Mallampati SR, Kaye AD, Urman RD (2014) Postoperative alterations in taste and smell. Anesth Pain Med 4:e18527

Gutiérrez AB, Rodríguez-Morales AJ, Narváez Mejía ÁJ, García Peña ÁA, Giraldo Montoya ÁM, Cortes Muñoz AJ, García AL, Ospina Serrano AV, Escobar BP, Acevedo Medina CA, Pardo González CA, Vargas Báez CA, Álvarez Moreno CA, Solórzano Ramos CA, Conde Martin CE, Saavedra Trujillo CH, Poveda Henao CM, Beltrán Arroyave CP, Sedano DS, Medina Ramos DC, Ortiz Marín DC, Rivera Rodríguez DE, Molina Ramírez DA, Suárez Castro EM, Müller EÁ, Medina EL, Monsalve ES, Guzmán EL, Vergara Vela EP, Buitrago EM, Medina FC, Sierra Matamoros FA, Fredy O Guevara P, Rodríguez Caicedo GA, Moreno GC, Ruiz GO, Roncancio Villamil GE, Ramírez HM, León González HL, Cordero HM, Hurtado IC, Rodríguez Sabogal IA, Gutiérrez IF, Patiño Niño JA, Castellanos JE, Guerra JC, Garzón Herazo JR, García JT, Carrillo Bayona JA, Cortés JA, Daza JC, Rojas Gambasica JA, Valderrama JF, Oñate Gutiérrez JM, Jaramillo Bustamante JC, López Cubillos JF, Osorio Lombana JP, Rojas Hernández JP, Bravo Ojeda JS, Gómez Rincón JC, Ordóñez Díaz KM, Arango KO, Estrada-Orozco K, Blanco LG, Rosado LM, Aguiar Martínez LG, de la Barrera LIM, Villa Sánchez LM, Melgarejo LM,
Garay Fernández MA, Gallego MP, Caro Flautero MA, Maya Restrepo MA, Martha I. Álvarez L, Leal NG, Opina N, Hoyos PV, Pabón PR, Arraut Collazos PB, Giraldo PF, López P, Lasso Palomino RE, Beltrán Higuera SJ, Valderrama SL, Remolina Granados SA, Cuervo Maldonado SI, Guerrero Lozano SJ, Restrepo Gualteros SM, Polo VA, Villamil Gómez WE (2020). Colombian consensus recommendations for diagnosis, management and treatment of the infection by SARS-COV-2/ COVID-19 in health care facilities - recommendations from expert's group based and informed on evidence. Infectio 24: 1-102

Hopkins C, Surda P, Kumar N (2020) Presentation of new onset anosmia during the COVID-19 pandemic. Rhinology 58:295-298

Lechner M, Chandrasekharan D, Jumani K, Liu J, Gane S, Lund VJ, Philpott C, Jayaraj S (2020) Anosmia as a presenting symptom of SARS-CoV-2 infection in healthcare workers - a systematic review of the literature, case series, and recommendations for clinical assessment and management. Rhinology. https://doi.org/10.4193/Rhin20.189

Lee Y, Min P, Lee S, Kim SW (2020) Prevalence and duration of acute loss of smell or taste in COVID-19 patients. J Korean Med Sci 35:e174

Moein ST, Hashemian SMR, Mansourafshar B, Khorram-Tousi A, Tabarsi P, Doty RL (2020) Smell dysfunction: a biomarker for COVID-19. Int Forum Allergy Rhinol. https://oi.org/10.1002/alr.22587

Ollarves-Carrero MF, Rodriguez-Morales AG, Bonilla-Aldana DK, Rodriguez-Morales AJ (2020) Anosmia in a healthcare worker with COVID-19 in Madrid, Spain. Travel Med Infect Dis 35:101666

Paniz-Mondolfi A, Bryce C, Grimes Z, Gordon RE, Reidy J, Lednicky J, Sordillo EM, Fowkes M (2020) Central nervous system involvement by severe acute respiratory syndrome coronavirus -2 (SARS-CoV-2). J Med Virol 92:699-702

Rahban C, Ailianou A, Jacot E, Landis BN (2015) Concomitant anosmia and ageusia: a case report. Rev Med Suisse 11:1787-1790

Reinhard A, Ikonomidis C, Broome M, Gorostidi F (2020) Anosmia and COVID-19. Rev Med Suisse 16:849-851

Rodriguez-Morales AJ, Cardona-Ospina JA, Gutierrez-Ocampo E, VillamizarPena R, Holguin-Rivera Y, Escalera-Antezana JP, Alvarado-Arnez LE, Bonilla-Aldana DK, Franco-Paredes C, Henao-Martinez AF, PanizMondolfi A, Lagos-Grisales GJ, Ramirez-Vallejo E, Suarez JA, Zambrano LI, Villamil-Gomez WE, Balbin-Ramon GJ, Rabaan AA, Harapan H, Dhama K, Nishiura H, Kataoka H, Ahmad T, Sah R, Latin American Network of Coronavirus Disease 2019 Latin American Network of Coronavirus Disease 2019-COVID-19 Research (LANCOVID-19) (2020a). Clinical, laboratory and imaging features of COVID-19: a systematic review and meta-analysis. Travel Med Infect Dis 34:101623

Rodriguez-Morales AJ, Rodriguez-Morales AG, Mendez CA, Hernandez-Botero S (2020b). Tracing new clinical manifestations in patients with COVID-19 in Chile and its potential relationship with the SARS-CoV-2 divergence. Curr Trop Med Rep. https://doi. org/10.1007/s40475-020-00205-2

Seiden AM (2004) Postviral olfactory loss. Otolaryngol Clin N Am 37:11591166

Tong JY, Wong A, Zhu D, Fastenberg JH, Tham T (2020) The prevalence of olfactory and gustatory dysfunction in COVID-19 patients: a systematic review and meta-analysis. Otolaryngol Head Neck Surg 194599820926473

van Riel D, Verdijk R, Kuiken T (2015) The olfactory nerve: a shortcut for influenza and other viral diseases into the central nervous system. J Pathol 235:277-287

Zhao H, Shen D, Zhou H, Liu J, Chen S (2020) Guillain-Barre syndrome associated with SARS-CoV-2 infection: causality or coincidence? Lancet Neurol 19:383-384

Publisher's note Springer Nature remains neutral with regard to jurisdictional claims in published maps and institutional affiliations. 